\begin{tabular}{|c|c|}
\hline & $\begin{array}{l}\text { International Journal of Trend in Scientific } \\
\text { Research and Development (IJTSRD) }\end{array}$ \\
\hline 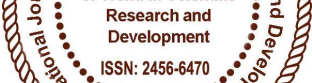 & International Open Access Journal \\
\hline 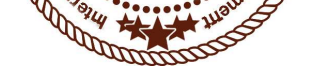 & ISSN No: 2456 - 6470 | www.ijtsrd.com | Volume - 2 | Issue - 2 \\
\hline
\end{tabular}

\title{
Analysis of Maternal Deaths in Oaxaca through Bayesian Networks
}

\author{
Araceli Pinacho-Ríos, Guillermo De la Torre-Gea \\ Sierra Sur University, Maxico
}

\begin{abstract}
Maternal mortality has shown a considerable decrease in countries where the rate of development is higher. This is not the case for Mexico where a large number of annual maternal deaths are still perceived, which turns out to be a public health problem in which the World Health Organization (WHO) considers indigenous populations with a higher rate of maternal deaths, as is the case in the state of Oaxaca. The aim of this paper is to carry out an analysis of maternal deaths during the period 2014-2016 in the municipalities of this state in order to identify the main causes that cause it, factors that intervene in it and municipalities with the highest rate of this problem. The analysis has revealed that the National Institute of Social Security (IMSS) is the site where the highest number of deaths occurred, as well as identifying the main causes that lead to maternal mortality, determining that it is not enough to have Public and Private Health institutions, but they must have a better care system and equipment for care, without leaving aside the cultural aspect of the inhabitants of the municipalities of the state of Oaxaca.
\end{abstract}

Keywords: Maternal mortality, public health, indigenous women, municipalities

\section{Introduction}

According to the World Health Organization (WHO), maternal mortality can be defined as "the death of a woman during pregnancy, delivery or within 42 days after termination, for any cause related or aggravated. for pregnancy, childbirth or puerperium or its management, but not for accidental causes ( Briones and Díaz de León, 2013).

Maternal mortality is a subject of vital importance for both the government and the general public. This problem must be of priority attention for the government, due to the diverse precarious conditions in which the health centers are located in marginalized areas of the country; which leads to higher rates of maternal mortality. The WHO asserts that where there are more cases of maternal mortality it is in places that present a lower rate: "maternal mortality is higher in rural areas and in the poorest communities" (WHO, 2016).

In Mexico, according to secondary analyzes of official data, between 1990 and 2013, a total of 29,822 women died due to maternal causes. For 2008, the Maternal Mortality Ratio (MMR) in the country was 57.2 , in 2010 it was 51.5, in 2012 it was 42.3 and in 2013, the last year with official statistics validated until May 2015, of 38.2 maternal deaths per 100,000 births. (Schiavon, 2015). In the case of Oaxaca, the female mortality rate according to data presented by INEGI (2015) was 11,225 deaths. These can have various causes, among them medical assistance, the reluctance of women to be treated and the working conditions and equipment in which the health sector is located. That is to say, the maternal mortality does not depend on the conditions of origin of the woman, but rather on the place of destination where it is attended to for childbirth.

It is necessary that governments focus attention on solving this global problem. In the specific case of Mexico, it is committed to "the goal of the 
International Journal of Trend in Scientific Research and Development (IJTSRD) ISSN: 2456-6470

Sustainable Development Goals is to reduce the maternal mortality ratio (MMR) worldwide to less than 70 per 100,000 live births between 2016 and 2030" (WHO, 2016). Therefore, the government must establish the appropriate measures to create public policies aimed at mitigating this global problem.

In view of the previous situation, the objective of this paper is to analyze the causes and effects of maternal mortality in Mexico, especially in women in situations of poverty and marginalization, as well as a minimum level of basic studies, in order to find a solution to the problem.

\section{Methodology}

Table 1: Study variables

\begin{tabular}{|c|c|c|}
\hline \multirow{3}{*}{$\begin{array}{l}\text { VARIABLE } \\
\text { SITIO_OCURRIO_DEF }\end{array}$} & VALUE & DESCRIPTION \\
\hline & $\infty$ & Al1: \\
\hline & 1 & IMSS -00 \\
\hline & $2 / 2$ & IMSS OPPORTUNITIES \\
\hline & 3 & ISSSTE CDD \\
\hline & 4 & HEALTH SECRETARY \\
\hline & 50 & SECRETARY OF NATIONAL DEFENSE \\
\hline & 6 & SECRETARY OF THE MARINA \\
\hline & 7 & PRIVATE MEDICAL UNIT C \\
\hline - & 8 & 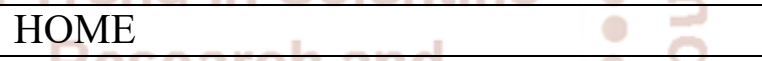 \\
\hline$=$ & 9 & PUBLIC ROAD \\
\hline & 10 & ANOTHER UNIT $n e n t$ \\
\hline & 110 & ANOTHER PLACE \\
\hline & 12 & IT IS IGNORED \\
\hline \multirow[t]{11}{*}{$\begin{array}{l}\text { DERECHO } \\
\text { HABIENCIA }\end{array}$} & 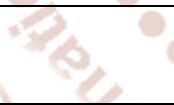 & TOUIV: $2400=0410.00$ \\
\hline & 0 & NOT SPECIFIC \\
\hline & 1 & ANY $1-1+2$ \\
\hline & $24 \mathrm{~N}$ & IMSS $>>$ \\
\hline & 3 & ISSSTE \\
\hline & 4 & PEMEX \\
\hline & 5 & SECRETARY OF NATIONAL DEFENSE \\
\hline & 6 & SECRETARY OF THE MARINA \\
\hline & 7 & POPULAR INSURANCE \\
\hline & 8 & ANOTHER UNIT \\
\hline & 10 & IMSS OPPORTUNITIES \\
\hline \multicolumn{3}{|l|}{ ESCOLARIDAD } \\
\hline & 0 & NOT SPECIFIC \\
\hline & 1 & ANY \\
\hline & 2 & INCOMPLETE PRIMARY \\
\hline & 3 & PRIMARY \\
\hline & 4 & INCOMPLETE SECONDARY \\
\hline & 5 & HIGH SCHOOL \\
\hline & 6 & BACCALAUREATE \\
\hline
\end{tabular}

For the development of the research, open data provided by the INEGI on the maternal mortality rate presented in the years 2012-2014 were considered. The selected variables were determined by the questions included in the survey, of which the following were chosen for analysis: the place where the death occurred, type of medical insurance, the level of schooling, usual occupation, medical assistance, the person who certified, as well as the mortality ratio.

Below is Table 1 showing the variables considered for this analysis. 
International Journal of Trend in Scientific Research and Development (IJTSRD) ISSN: 2456-6470

\begin{tabular}{|c|c|c|}
\hline & 7 & PROFESSIONAL \\
\hline \multicolumn{3}{|l|}{ QUIEN CERTIFICO } \\
\hline \multirow[t]{6}{*}{ LA DEFUNCIÓN } & 1 & TREATING MEDICAL \\
\hline & 2 & MEDICAL EXAMINER \\
\hline & 3 & OTHER DOCTOR \\
\hline & 4 & PERSONNEL AUTHORIZED BY S.S.A. \\
\hline & 5 & CIVIL AUTHORITY \\
\hline & 8 & OTHER \\
\hline \multicolumn{3}{|l|}{$\begin{array}{l}\text { OCUPACIÓN } \\
\text { HABITUAL }\end{array}$} \\
\hline & 0 & NOT SPECIFIC \\
\hline & 2 & NOT BUSSY \\
\hline & 4 & AGRICULTURE, LIVESTOCK, FISHING \\
\hline & 11 & PROFESSIONALS \\
\hline & 12 & TECHNICAL U \\
\hline & $13 \sim$ & WORKERS OF EDUCATION \\
\hline & 62 & SUPPORT TO ACT. ADMITIVES. \\
\hline & 98 & DOES NOT APPLY UNDER 12 YEARS OLD \\
\hline \multirow[t]{3}{*}{ ASISTENCIA MÉDICA } & $0 \times 0$ & NOT SPECIFIC \\
\hline & 1. & WITH MEDICAL ASSISTANCE \\
\hline & 20 & WITHOUT MEDICAL ASSISTANCE \\
\hline \multirow[t]{3}{*}{$\begin{array}{l}\text { RAZÓN } \\
\text { MORTALIDAD }\end{array}$} & 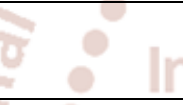 & ternational Journal \\
\hline & 10 & $\begin{array}{l}\text { MATERNAL DEATHS FOR THE REASON OF MATERNAL } \\
\text { MORTALITY }\end{array}$ \\
\hline & 2 & $\begin{array}{l}\text { MATERNAL DEATHS EXCLUDED FOR THE REASON OF } \\
\text { MATERNAL MORTALITY }\end{array}$ \\
\hline
\end{tabular}

The treatment of the selected variables was carried out through the use of Elvira software, which is oriented to the edition and evaluation of Bayesian network models and influence diagrams. Bayesian networks have different applications, for classification, prediction, diagnosis and provide relevant information on relationships between variables that can be interpreted as causes and effects (Ramírez-Madrigal, 2018; Rentería-Gaeta, 2018; De la Torre-Gea et al., 2016). In this sense, the relationships between seven groups of variables are analyzed.

\section{Analysis of results}

The results obtained from the analysis of the variables related to maternal mortality show that there is a greater relationship between the place where the death occurred, followed by the medical assistance provided. There is also a relationship between the mother's occupation, schooling and the type of Social Security she had. In addition, it is possible to appreciate the existence of independent variables that do not directly influence the developed problem, such as locality of residence, size of the locality, conjugal status, municipality of occurrence, age of the mother and the cause of mortality. As shown in Figure 1. 


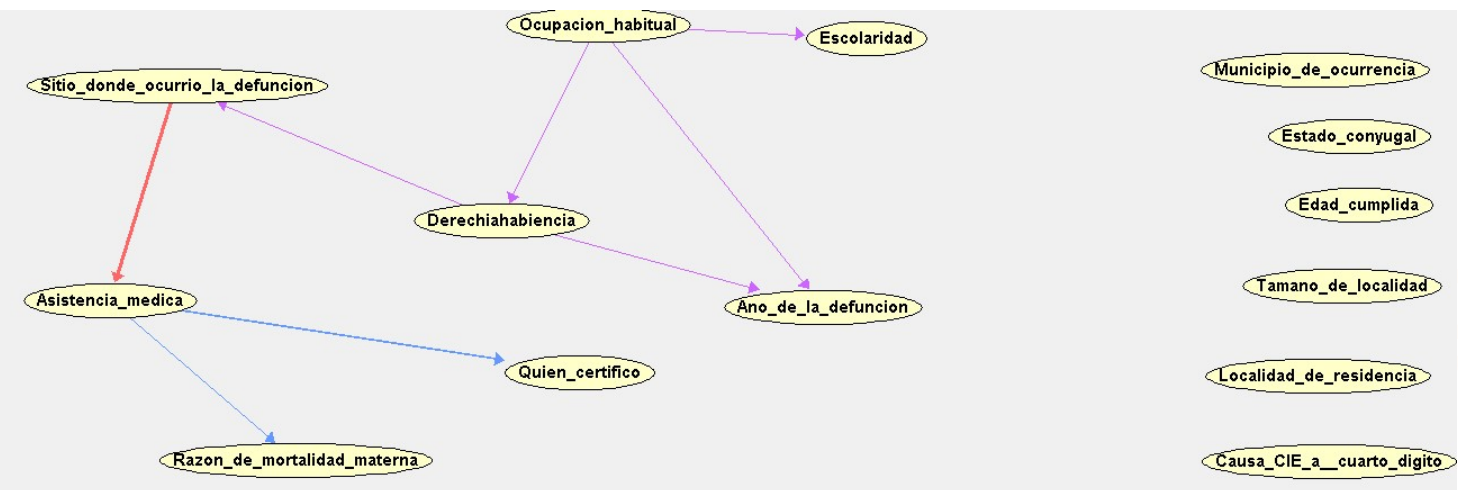

Figure 1: Dependent and independent variables of maternal mortality

An important finding identified in the previous figure, where the data presented by the World Health Organization contradict, which affirm that the highest maternal mortality rate occurs in indigenous populations, considering this as the determinant of the problem. However, the analysis of the variables shows a different result, being, in this case, the place where the death has presented a factor of influence in the proposed topic.
In the same way the study shows an a priori probability where it determines that the maternal deaths were carried out in people who were not currently working, and the schooling they presented was basic representing $25 \%$ of the total sample, counting only with Insurance Popular, without having access to the right to know the IMSS, this institution being the place with the highest mortality rate presenting $28 \%$ of the total, followed by another place not specified with $26 \%$. These results are shown in Figure 2.

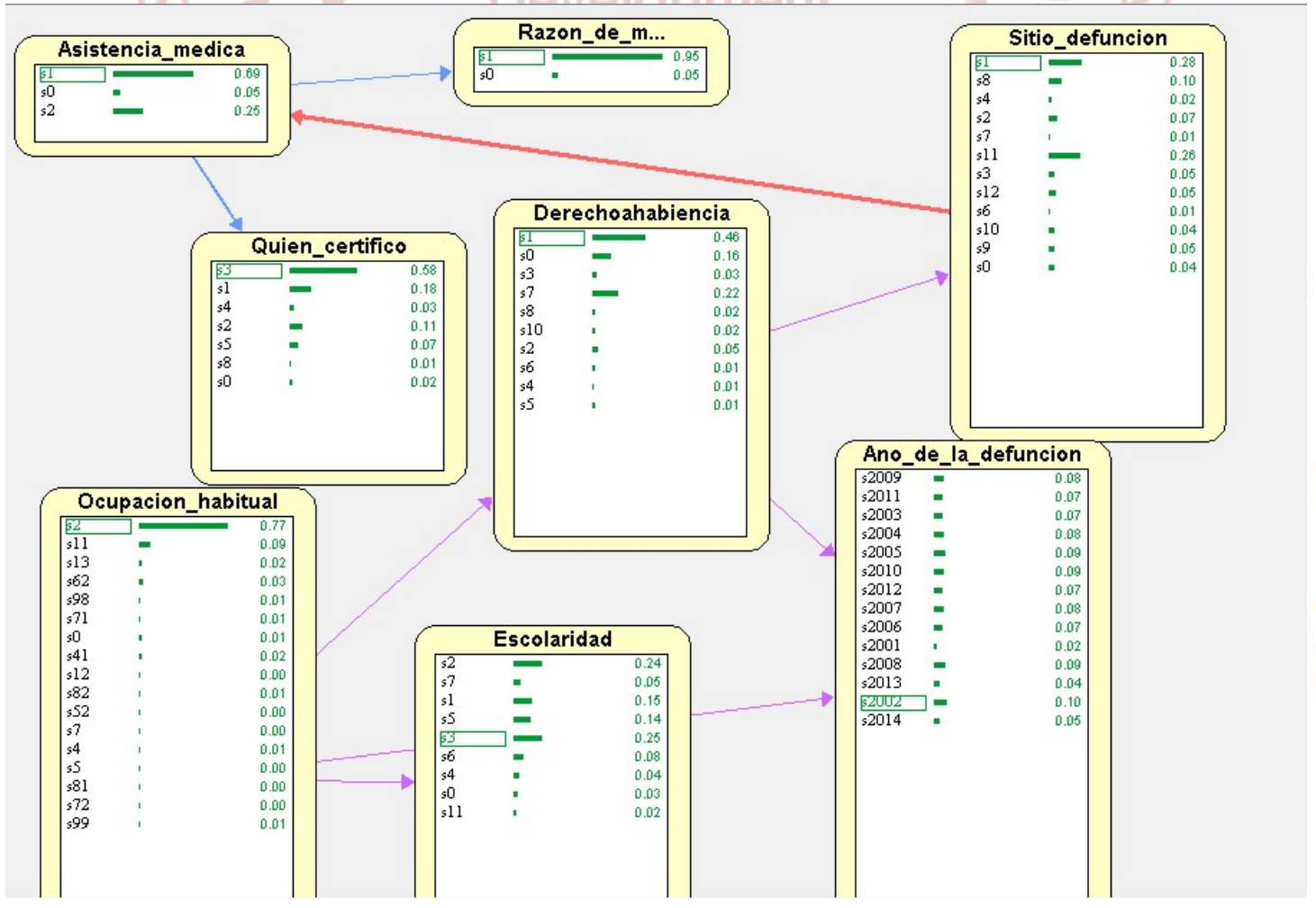

Figure 2: A priori probabilities of the study variables 
Knowing that they died in the IMSS, it is identified that $77 \%$ of the mothers did not find themselves with any occupation, having a primary school level and content at the time of their demise with Seguro Popular in this institution.
These women were treated in this medical institution and $94 \%$ of them died for reasons of maternal mortality. The analysis allowed to know that the doctor who had certified the decease was not the same one that attended the prenatal control and delivery. As shown in Figure 3.

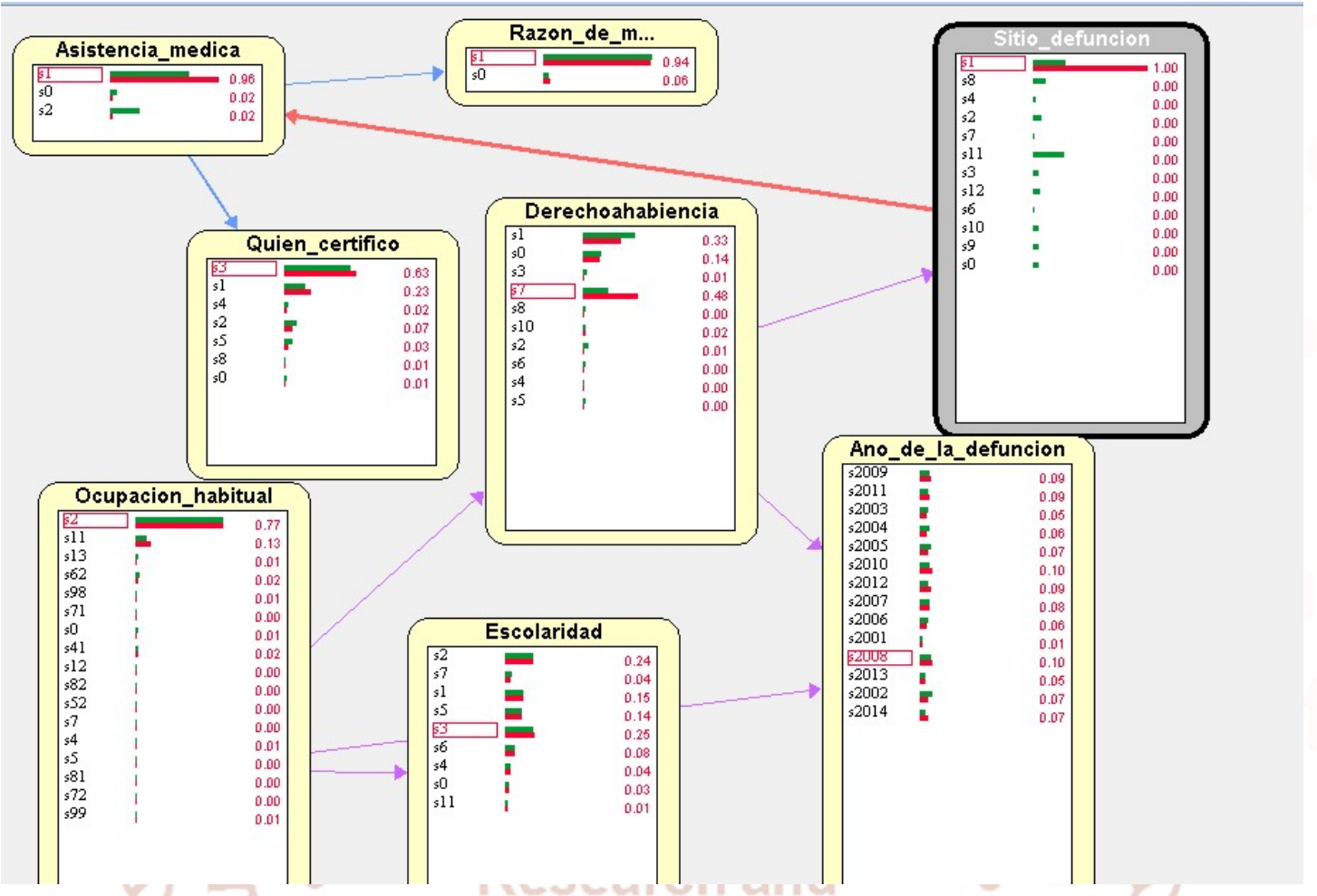

Figure 3: Inference Model where the death site was the IMSS

Despite the previous figure in 2008 and 2010, there is a $10 \%$ of deaths from the total analysis, but in 2014 this event decreases to $7 \%$, which may deduce that measures are being taken to control the problem before mentioned.

\section{Conclusions}

To conclude with the analysis of the variables on the subject of maternal mortality, it is determined that the state of Oaxaca still presents problems in the health issue, since the data presented in this study show that the characteristics that the WHO assumes as variables The determinants of maternal mortality (poverty, underdevelopment, marginalization) are not really significant in this global health problem.

In addition, in view of the evident commitment of the countries to end this worldwide problem, it is also concluded that they have really taken no action to counteract this situation. It is opportune to pay attention and carry out an analysis that allows us to really determine which factors influence this problem, far from the poverty and marginalization of the right holders of health.

The population where the problem was presented lacks education, this is reflected in their level of study being only basic, coupled with the above is the situation where people are not working and this limits them to not have the right of any institution of public health, being their social security the Seguro Popular.

The awareness of the government and citizens about the need to have medical infrastructure is not enough. It is urgent to seek the quality of the institutions in charge of providing this health service to pregnant women, who fit in a population considered to be socially vulnerable. In addition, it requires a total commitment to public servants (doctors and nurses) involved in its implementation. Only by combining labor commitment and political will in this matter will efficiency and effectiveness in its provision in the state of Oaxaca be achieved. 


\section{References}

1. Briones J, Díaz de León M, y Meneses C. (2009). Estrategias para reducir la mortalidad materna hospitalaria en el estado de México. Rev Asoc Mex Med Crit Ter Int 2009, Vol 23(1); 16-24.

2. Briones J, y Díaz de León M. (2011). Muerte materna y medicina crítica. Asoc Mex Med Crít Ter Int 2011;25(2):56-57.

3. Briones, J. Gómez, B. Díaz de León, M. Briones V, Rodríguez RMM: Hemorragia

4. Briones, J. y Díaz de León, M. (2013). Mortalidad Materna. México: IMSS.

5. Cerebral en preeclampsia--eclampsia. Rev Asoc Mex Med Crit Ter Int 2003; 17(4): 133--137..

6. De la Torre-Gea, G., Delfín-Santisteban, O., Torres-Pacheco, I., Soto-Zarazúa, G., GuevaraGonzález, R., Rico-García, E. (2014). Redes Bayesianas aplicadas a un modelo CFD del entorno de un cultivo en in invernadero. Agrociencia, 48(3): 307 - 319 .

7. Instituto Nacional de Estadística y Geografía (2012-2014). Datos abiertos de mortalidad materna. INEGI.

8. Instituto Nacional de Estadística y Geografía (2015). Defunciones Generales Mujeres, Oaxaca. INEGI.

9. Organización Mundial de la Salud (2016). Mortalidad Materna. Recuperado desde: http:/www.who.int/mediacentre/factsheets/fs348/ es/

10. Fajardo-Dolci, G., Meljem-Moctezuma, J., Vicente-González, E., Venegas-Páez, F., VillalbaEspinoza, I., Pérez-Cardoso, A., Barrón-Saldaña, D., Montesinos-Gómez, G., Aguirre-Güemez, A., Novoa-Boldo, A., Mendoza-Larios, L., LópezGonzález, R., Mazón-González, B., \& AguirreGas, H. (2016). Análisis de las muertes maternas en México ocurridas durante 2009. Revista MéDica Del Instituto Mexicano Del Seguro Social, 51(5), 486-495.
11. Schiavon, Raffaela. (2015) "Mortalidad Materna: un Problema de Salud Pública y de Derechos Humanos" en Derechos sexuales y reproductivos de las mujeres. Avances y retos a 20 años de las Conferencias Mundiales de El Cairo y Beijing.

12. SEDESOL, SEP, SSP, (2002). Un México apropiado para la infancia y la adolescencia. Programa de acción 2002--2010.

13. Ramírez-Madrigal, C., De la Torre-Gea, G. (2018). PERCEPTION OF SECURITY IN MEXICO THROUGH BAYESIAN NETWORKS. International Journal of Trend in Scientific Research and Development, 2(2): 1244 $-1252$.

14. Rentería-Gaeta, R., De la Torre-Gea, G. (2018). Bayesian analysis of internet access through apps as an e-government development strategy in Mexico. International Journal of Trend in Scientific Research and Development, 2(2): 1070 $-1074$.

15. Távara, L. Intervenciones para reducir la mortalidad materna en el Perú. Revista Peruana de Ginecología y Obstetricia, vol. 52, núm. 3, 2006, pp. 140-141.Sociedad Peruana de Obstetricia y Ginecología San Isidro, Perú. 